\title{
Factors affecting career plans of faculty of pharmacy students in Ege University and their evaluations about career symposium
}

\author{
Bülent KIRAN ${ }^{*, 1}$, Elif Gizem KARACA ${ }^{1}$ \\ 1 Department of Pharmacy Management, Faculty of Pharmacy, Ege University, Bornova 35040 Izmir, Turkey
}

\begin{abstract}
Career choice is one of the most important decisions affecting human life substantially and determines the future in material and psychological aspects. This research performed to evaluate 1-day career training program, determine students' future career plans, factors influencing career choice and training needs, ascertain level of anxiety about future of Ege University's Pharmacy Faculty students. It is a descriptive research. Population includes Ege University's Pharmacy Faculty students participating symposium. Data obtained by self-reporting of 12 -question survey by 100 -students and evaluated with frequency, percentage distribution, chi-square and fisher's exact test by SPSS-18. It was found that more than half (56\%) of the students were members of low-and-low-middle income group and these students want to work in public sector, $92 \%$ has anxiety about issues such as low wages, unemployment and failure to work on desired field. $49 \%$ of students has more than one career choice, and there is statistically significant differences between gender, parents' educational background and post-graduation working area choices. $51 \%$ of students were found symposium participated in for shaping future career plans is effective, $90 \%$ were found symposium useful, $93 \%$ were needed career planning trainings and symposiums during undergraduate studies for recognize career areas and raise awareness in pharmacy. For clarifying students' career goals during the undergraduate, as elective courses may be added to curriculum, organization of events such as symposium, seminar, establishment of counseling offices in universities and increasing internships' effectiveness will be useful. Concordantly, it is thought that accreditation process of pharmacy faculties will provide opportunity for new regulations.
\end{abstract}

KEYWORDS: Pharmacy ; career choice ; pharmacy education ; pharmacy students

\section{INTRODUCTION}

Career is a concept that expresses works of employees during their business life and their progress in professional life regardless of their organizational position [1,2]. Turkish Language Association is defining career concept as "degree, success and expertise acquired through time and work in a profession" [3]. Career is affecting people's lives to a large extent in terms of both concrete elements such as obtaining financial power to maintain their life's and determination of social status, and psychological factors such as ensuring job satisfaction and personality development $[2,4]$. Therefore, for occupational satisfaction; it is important to consider personal values, interests, skills, needs and cultural values in career choice [5].

In this new period with conditions of finding and maintain a job getting harder and harder every day and aimed in many business areas to operate intelligent machines with zero error and low cost in the near future known as the 4th Industrial Revolution, determining future career plans of students from university years and developing themselves to achieve these career goals become even more important when considered

Received: $\quad 21.06 .2017$ / Accepted: $\quad 09.08 .2017$

Corresponding Author: Bülent Kıran

E-mail: kiran.bulent@gmail.com

Phone: +902323113979

ORCID No: https://orcid.org/0000-0001-8734-6095 that employment capacity will decrease and unemployment rates are likely to increase [6,7]. As a matter of fact, it is observed that the students who do not determine career orientations during university years are beginning to work in an unplanned way after graduation, and this causes waste of time and resources in the process of achieving their career steps [8].

In this context, business world is expected from universities to educate appropriate human resources for the qualifications they seek, and students are expected from universities to prepare themselves for the profession and to make contribution their personal development $[9,10]$. Therefore, as well as scientific information development and dissemination activities, cultivating manpower resources that will provide the development of the country became one of the main objectives of the universities [9]. However, it is also very difficult to realize all these expectations by teaching towards only specific areas of specialization. Therefore, in recent years, career centers have been established, various career symposiums were organized, activities such as meeting with the representatives of the sector were performed within the

How to cite this article: Kıran B, Karaca EG. Factors affecting career plans of faculty of pharmacy students in Ege University and their evaluations about career symposium. Marmara Pharm J. 2018; 22 (1): 37-43. 
universities $[8,9]$. In this way, it is aimed to raise awareness about the career field and employment opportunities that students will choose in the future.

One of the works carried out to help students' career choose is "Select Your Future Career Symposium" performed every year since 2014 in cooperation with Ege University Faculty of Pharmacy and Izmir Chamber of Pharmacist. In the career symposium; sessions were carried out for community pharmacy, hospital and clinical pharmacy, governmental pharmacy (which pharmacists work in Social Security Institution, Ministry of Health and other governmental institutons), academic pharmacy and industry pharmacy and well-known pharmacists in their field were provided to meet students in an interactive environment.

The objective of this research is to evaluate the effectiveness of the "Career Orientations in Pharmacy Symposium Select Your Future-3" one-day event held in April 2, 2016 and to determine thoughts on future career plans and the factors that affect the future career choices of the students participating in the symposium, and to detect concerns about their career plans, trainings and assistance they need.

\section{RESULTS AND DISCUSSION}

While $77 \%$ of the students participating in the research are female and $23 \%$ are male students. It is stated that $39 \%$ of the students have $3901 \mathrm{TL}$ and above (1212.6€ and above) monthly family income, and 33\% have between 2601-3900 TL (808.5-1212.3€). When the perceived economic status of families evaluated, it was found that $91 \%$ of the students belong to a middle-class family (Table 1).

In addition, mothers of $43 \%$ of the students and fathers of $59 \%$ of the students who participated in the survey were university graduates (Table 1). According to researches, as well as psychological factors such as interest, skill, professional value, perception and attitudes, elements such as age, gender, social background, education level and economic situation of the family, social environment are also effective in the career choices of individuals $[12,13]$. In a study conducted by high school students in Denizli in 2014, it was found that the socio-economic statuses of the families are effective in academic achievements of students and the earnings to be obtained after university [14]. In this context, it was examined whether there is a statistically significant difference between family monthly income of students participating in the survey and the preferences of the pharmacy area (area of specialization) where they plan to work after graduation. The relation between family monthly incomes and "choice of public pharmacy" as a postgraduate working area (Fisher's exact test; $\mathrm{p}=0.010$ ) and between family monthly incomes and "choice of military pharmacy" as a post-graduate working area (Fisher's exact test; $p=0.030$ ) were found statistically significant. "Lowmiddle and low" income level students who have "2600 TL and below" (808.2€ and below) family monthly incomes are more inclined to prefer "public and military pharmacy" fields as a post-graduate working area when compared to the students in the "middle and above income" group. When it is considered that opening a community pharmacy business requires a significant accumulation of capital, it is an expected result that students belonging to "low and lowmiddle" incomes want to be a worker in the public and as a military pharmacist in armed forces instead of pharmacy ownership.

On the other hand, when the relationship between the educational status of the parents and choice of post-graduate working area is examined statistically; it was found that students whose father's education status is "high school graduate and below" are more inclined to prefer "military pharmacy" as a post-graduate working area when compared to other students (Fisher's exact test; $p=0.004$ ). It was also found that students whose mother's education status is "high school graduate and below" are more inclined to prefer "public pharmacy" (Fisher's exact test; p = 0.044) and "military pharmacy" as a post-graduate working area when compared to other students (Fisher's exact test; $\mathrm{p}=$ 0.0001). According to the results of the "Earnings Survey" conducted by TURKSTAT in 2014; it was found that the earnings of employees are increased in direct proportion to their educational status, those with higher education level have the highest annual average gross earnings [15]. In light of these findings, as the income level of the family is expected to decrease mostly when the level of education decreased in our study; it suggests that students whose families have low income want to be a worker instead of pharmacy ownership.

When the relationship between gender of students participating in the study and pharmacy areas they planned to work after graduation is examined; statistically significant difference was found between choice of public pharmacy and gender (Fisher's exact test; $p=0.024$ ) and between choice of clinical pharmacy and gender $\left(x^{2}=4,150 ; p=0.042\right)$. It was also found that the tendency of male students to choice "public pharmacy" as a post-graduate working area is more than female students, and the tendency of female students to choice "clinical pharmacy" as a post-graduate working area is more than male students. In a study conducted in England in 2006, there was a significant difference between gender and the choice of post-graduate working area tendency. While female students were more likely to prefer hospital pharmacy, male students tend to prefer community pharmacy [16]. In our research, the reason why male students in Turkey prefer to be a worker in the public sector is due to their lack of capital to open a pharmacy because they are within mostly families with low and low-middle economic status. 
Table 1. Sociodemographic attributes of students

\begin{tabular}{|c|c|c|}
\hline \multirow{2}{*}{ Gender } & $\mathrm{N}(100)$ & \multirow[t]{2}{*}{$\%$} \\
\hline & & \\
\hline Female & 77 & 77 \\
\hline Male & 23 & 23 \\
\hline Monthly Income of Families & & \\
\hline $1300 \mathrm{TL}$ and Below (404,1€ and Below) (Low) & 2 & 2 \\
\hline 1301-2600 TL (404,4-808,2€) (Low-Middle) & 21 & 21 \\
\hline 2601-3900 TL (808,5-1212,3€) (Middle) & 33 & 33 \\
\hline $\begin{array}{l}3901 \mathrm{TL} \text { and Above (1212,6€ and Above) (Middle and } \\
\text { Above) }\end{array}$ & 39 & 39 \\
\hline Unidentified & 5 & 5 \\
\hline Perceived economic status of the family & & \\
\hline Poor & 2 & 2 \\
\hline Middle class & 91 & 91 \\
\hline Rich & 2 & 2 \\
\hline Unidentified & 5 & 5 \\
\hline Mother's Education Status & & \\
\hline Illiterate & 0 & 0 \\
\hline Literate & 0 & 0 \\
\hline Primary school graduate & 7 & 7 \\
\hline Secondary school graduate & 14 & 14 \\
\hline High school graduate & 34 & 34 \\
\hline University graduate & 43 & 43 \\
\hline Postgraduate (Master-PhD) & 1 & 1 \\
\hline Unidentified & 1 & 1 \\
\hline Father's Education Status & & \\
\hline Illiterate & 0 & 0 \\
\hline Literate & 0 & 0 \\
\hline Primary school graduate & 5 & 5 \\
\hline Secondary school graduate & 8 & 8 \\
\hline High school graduate & 24 & 24 \\
\hline University graduate & 59 & 59 \\
\hline Postgraduate (Master-PhD) & 3 & 3 \\
\hline Unidentified & 1 & 1 \\
\hline
\end{tabular}

$41 \%$ of the students who participated in the research are 3 rd grade students. It is thought that the participation in the symposium for the students in this group may have increased because vocational lessons (pharmaceutical chemistry, pharmaceutical technology, pharmacologypharmacotherapy, pharmacognosy, pharmacy management etc.) begin at 3rd grade. When students are asked reason for preference the faculty of pharmacy, it was found that approximately half $(51 \%)$ of them want to work in the healthcare field and their assessment selection and placement center score was enough for the faculty of pharmacy. In addition, it was found that $24 \%$ of the students are interested in pharmacy and $16 \%$ preferred faculty of pharmacy because it is "a profession that offers respectable, comfortable, profitable and good future" (Table 2). In other studies on students who prefer healthcare field in career selection, it was shown that factors such as indispensability of healthcare services, job guarantee, wide working area, importance given to health professions are effective in student's choice of profession $[17,18]$. These factors are thought to be also effective on students who prefer pharmacy faculties.

Table 2. Post-Graduate working area planned by students

\begin{tabular}{|c|c|c|}
\hline \multirow{2}{*}{ Grade } & $\mathrm{N}(100)$ & $\%$ \\
\hline & & \\
\hline 1. Grade & 20 & 20 \\
\hline 2. Grade & 8 & 8 \\
\hline 3. Grade & 41 & 41 \\
\hline 4. Grade & 13 & 13 \\
\hline 5. Grade & 14 & 14 \\
\hline Unidentified & 4 & 4 \\
\hline Reason For Faculty Of Pharmacy Preference & & \\
\hline $\begin{array}{l}\text { He/she wants to work in the healthcare field } \\
\text { and assessment selection and placement center } \\
\text { score was enough for the faculty of pharmacy. }\end{array}$ & 51 & 51 \\
\hline . He/she is interested in pharmacy & 24 & 24 \\
\hline $\begin{array}{l}\text { - Because it is a profession that offers respectable, } \\
\text { comfortable, profitable and good future }\end{array}$ & 16 & 16 \\
\hline $\begin{array}{l}\text { - Because he/she has curiosity on research and to } \\
\text { make discoveries }\end{array}$ & 4 & 4 \\
\hline $\begin{array}{l}\text { Because he/she is interested in chemistry so } \\
\text { much }\end{array}$ & 1 & 1 \\
\hline With family, spouse, friend advice & 1 & 1 \\
\hline - Because his/her mother or father is a pharmacist & 1 & 1 \\
\hline Unidentified & 2 & 2 \\
\hline Post-Graduate Working Area Planned & $\mathrm{N}(184)$ & $\%$ \\
\hline Community Pharmacy & 43 & 23,4 \\
\hline Clinical Pharmacy & 40 & 21,7 \\
\hline Industry Pharmacy & 37 & 20,1 \\
\hline Hospital Pharmacy & 28 & 15,2 \\
\hline Academic Pharmacy & 22 & 12 \\
\hline Military Pharmacy & 7 & 3,8 \\
\hline Governmental Pharmacy* & 6 & 3,3 \\
\hline Unidentified & 1 & 0,5 \\
\hline
\end{tabular}

${ }^{*}$ which pharmacists work in Social Security Institution, Ministry of Health and other governmental institutons

When the students who participated in the research are asked about post-graduate working area planned; $23.4 \%$ of them were preferred community pharmacy, $21.7 \%$ were clinical pharmacy, $20.1 \%$ were industrial pharmacy, 15,2\% were hospital pharmacy, $12 \%$ were academic pharmacy. It was found that the remaining $7.1 \%$ of the students want to work in military pharmacy and public pharmacy fields (Table 2).

However, it was found that almost half (49\%) of the students who participated in the survey has more than one career field preference on post-graduate working area. This suggests that students are undecided about the post-graduate 
working area. On the other hand, $92 \%$ of the students who participated in the survey expressed concerns about the future of pharmacy; it was found that $13 \%$ were expressed concerns about unemployment, $22.6 \%$ about low wages, $28.7 \%$ about failure to work in the desired field and $33.6 \%$ were concerned about all three issues (Table 3). In this context, it is thought that concern of students on failure to work in the desired field may be effective if they select more than one choice for post-graduate working area. In a similar study conducted in $2015,77.5 \%$ of the students have a concern about the future of the profession, it was determined that $34 \%$ of the students wanted to work in the field of community pharmacy after graduation, and it was observed that working choice in $(8.8 \%)$ the pharmaceutical industry and $(3.9 \%)$ in the hospital pharmacy is lower when compared to our research [19]. The reduction in interest in community pharmacy in our research compared to work made in 2015 and on the other hand, increasing trend towards areas such as pharmaceutical industry and hospital pharmacy suggest that Pharmacy Law No. 6308 and the application of the 1 pharmacy limitation per 3500 population in the opening of community pharmacy introduced by this law increase its influence on students' preferences.

It is examined whether there is a significant difference between gender of students participating in the study and their concerns experiencing about the future of pharmacy, and it is found that there is not any statistically significant difference $\left(x^{2}=0.020 ; p>0,05\right)$. In addition, the relation between students' family economic status and the concerns about the future of pharmacy are also examined and no statistically significant difference was found $\left(x^{2}=0.860\right.$; $\mathrm{p}>0,05)$. In a study conducted with students studying at secondary education institutions, there was a statistically significant difference between students' academic and professional future concerns and gender. The academic and occupational future concerns of female students were higher than male students [20]. In another study conducted with high school students and aimed at determining the level of unemployment concern among students, it was observed that concern levels of male students were higher than female students [21].

Table 3. Students' opinions about the future of pharmacy

\begin{tabular}{|l|l|l|}
\hline & $\mathbf{N}$ & $\%$ \\
\hline Concern About the Future of the Profession & $\mathbf{N}(\mathbf{1 0 0})$ & \\
Yes & 92 & 92 \\
No & 8 & 8 \\
Students' Concerns & $\mathbf{N}(115)$ & $\%$ \\
All & 39 & 33,9 \\
Failure To Work In The Desired Area & 33 & 28,7 \\
Working With Low Wage & 26 & 22,6 \\
Unemployment & 15 & 13 \\
Other & 1 & 0,9 \\
Unidentified & 1 & 0,9 \\
\hline
\end{tabular}

As regards the evaluation of the symposium, $90 \%$ of the participants in the research were found "Career Symposium" useful and 93\% stated that they need such career days and symposiums. Furthermore, when the opinions of the students on the quality of the symposium were examined; $83 \%$ of the participants were found the date, $82 \%$ the guests, $78 \%$ the duration and $75 \%$ the content of the symposium appropriate and sufficient. On the other hand, approximately half (51\%) of the students stated that the symposium was effective in shaping their future career plans.

Table 4. Students' opinions about "Choose Your Future 3" Career Symposium

\begin{tabular}{|c|c|c|c|c|c|c|}
\hline & Strongly Agree & Agree & Neutral & Disagree & \begin{tabular}{|l} 
Strongly \\
Disagree
\end{tabular} & Unidentified \\
\hline There is a need for Career Days in pharmacy & $83(\% 83)$ & $10(\% 10)$ & $2(\% 2)$ & $1(\% 1)$ & $3(\% 3)$ & $1(\% 1)$ \\
\hline I found "Choose Your Future-3 Symposium" Useful & $56(\% 56)$ & $34(\% 34)$ & $5(\% 5)$ & $2(\% 2)$ & $2(\% 2)$ & $1(\% 1)$ \\
\hline The Symposium's Duration is Enough & $47(\% 47)$ & $31(\% 31)$ & $13(\% 13)$ & $3(\% 3)$ & $5(\% 5)$ & $1(\% 1)$ \\
\hline The Symposium's Date is Appropriate & $60(\% 60)$ & $23(\% 23)$ & $9(\% 9)$ & $2(\% 2)$ & $4(\% 4)$ & $2(\% 2)$ \\
\hline The Symposium's Content is Appropriate and Sufficient & $41(\% 41)$ & $34(\% 34)$ & $18(\% 18)$ & $6(\% 6)$ & $1(\% 1)$ & - \\
\hline Guests Have Full and Extensive Knowledge About The Subject & $40(\% 40)$ & $42(\% 42)$ & $13(\% 13)$ & $2(\% 2)$ & $3(\% 3)$ & - \\
\hline The Symposium Affected My Future Career Plans & $22(\% 22)$ & $29(\% 29)$ & $37(\% 37)$ & $8(\% 8)$ & $4(\% 4)$ & - \\
\hline
\end{tabular}


Super has stated that career development is lasted from childhood until death [22]. According to a study conducted in 2007, professional career education and consultancy services must be applied from primary school age in order to be able to keep up with the developments and globalization in terms of social and technological aspects in the 21st century and to successfully transition of young people from education life to business life, thus, it is thought that students may recognize different professions and explore their interests, and able to make more conscious choices, establish relation between what they learned and their working life and can use their leisure time effectively [23].

Research conducted by high school students in this regard, it is observed that psychological counseling and vocational guidance activities are effective factors in individual career planning and there is a significant difference between those who received and those who do not receive vocational guidance services in terms of professional maturity $[24,25]$. In another study carried out with university students, it was found that students' career goals and sector preferences are depending on the universities they were studying. Accordingly, it has been found that opportunities provided by the universities such as internship, career days and trainings are effective in career development of students [26].

On the other hand, the number of public and foundation universities in the higher education system increases day by day in our country. This numerical increase has created a competitive environment among the universities in order to increase the quality of education offered, to educate students in line with the needs and expectations of the business world and to create employment after graduation. Thus, career centers have been established in many universities [27].

Career centers established within universities are interorganizational organizations that allow students evaluate themselves and consciously plan their careers [9.27]. In these organizations; services such as career orientation consultancy, internship organization, temporary/part-time work organization, company outings, career and personal development seminars, business world meetings and introductory meetings and career day events are offered [9].

These organizations, established in the United States at the beginning of the 1900's, have started to be established in our country in the 1990s, especially come to the fore in recent years [9]. Accordingly, "Career Centers Meeting" was organized in June 2013 by the Council of Higher Education and emphasized the importance of career centers ensuring to educate the students in accordance with the needs and expectations of the business world, to prepare for business life, to increase employment opportunities and to carry out internship practices effectively [28].

\section{CONCLUSION}

It was found that approximately half of the undergraduate students participating in the research have not exact decision on post-graduation working area and the vast majority (92\%) is concerned about the future of the pharmacy profession. These concerns include "unemployment", "failure to work in the desired field" and "working with low wages".

It was found that $91 \%$ of the students were described their families' perceived economic status as "middle-class", more than half (56\%) were stated that the monthly income of their family was between TL 1301-3900 (404.4-1212.3€). It is understood that "low-middle and low" income level students are more inclined to prefer "public and military pharmacy" fields as a post-graduate working area when compared to the students in the "middle and above income" group.

On the other hand, it was found that the majority of the students (93\%) found activities and trainings such as career day symposium in pharmacy etc. useful in order to be able to prefer future career areas effectively and efficiently. In addition, it was also found that $90 \%$ of the students found useful "Career Orientations in Pharmacy Symposium Select Your Future-3" aiming to help students to determine their career goals. $51 \%$ of the students stated that the symposium directly affected their future career plans.

\section{Recommendations}

In light of all these results, it is thought that organizing activities such as career days within the faculties, and courses and seminars, workshops for areas of profession will be beneficial in order to be able students to identify their career goals during undergraduate study and to carry out their works in this direction. In addition, when considered that vocational internships are also an important factor in determining the career field, it may be useful to make regulations for increasing the efficiency of vocational training courses carried out during the undergraduate study. On the other hand, as well as centers within the universities', career offices can also be established within the faculty and thus, it can be ensured that students may determine their career field and targets in communication with these offices and centers from their first year of university and can benefit from internship and training opportunities more effectively. In Turkey, with beginning of accreditation processes in pharmacy education and the accreditation of some pharmacy faculties, it is thought that it provides an important opportunity for restructuring in education according to the requirements of the age and it should be benefited.

\section{MATERIALS AND METHODS}

It is a cross-sectional and descriptive research. Population includes 100 students studying in 1st-5th grades in Ege University Faculty of Pharmacy participating in the "Select Your Future 3" symposium. The survey form which developed for this research composed of 11 questions and 7 statements in the form of 5 point Likert scale prepared by researchers after literature review, survey is applied to all students 
attending the symposium on a volunteer basis and 100 students answered with self-reporting. In order to determine the family monthly income of the students participating in the survey, a scale was prepared by researchers. The researchers are used "minimum wage" determined by law in Turkey in this scale as base. Minimum wage is the amount sufficient to meet the essential needs of the workers at the minimum level. The net minimum wage for the year 2016 determined by the Turkish Social Security Institution is 1300 TL. A four-dimensional scale consisting of the net minimum wage and its multiples was prepared [11]. In this scale prepared accordingly, "1300 TL and below" (404,1€ and below) refers to "low income" level, "between 13012600 TL" (404,4-808,2€) refers to "low-middle income" level, "between 2601-3900 TL" (808,5-1212,3€) refers to "middle income" level, and "3901 TL and above" (1212,6 € and above) refers to "middle and above income" level. In order to be able to compare the research with international studies and to increase its understanding, Euro-equivalents of TLbased wages on the scale were calculated by using selling rate of exchange of Central Bank of the Republic of Turkey corresponding to the first Monday of January in 2016. As well as the family monthly income level, "perceived economic status of the family" was also determined by asking another question about how they define the economic situation of their families ("poor", "middle-class", "rich") and statistical analyzes of the obtained data were evaluated by frequency, percentage distribution, chi-square and Fisher's exact tests by using SPSS 18 packaged software.

\section{Acknowledgements}

The authors, would like to thank Turkish Pharmacists' Association (TPA) 3rd District İzmir Chamber of Pharmacist, who contributed and supported the symposium and research.

\section{Authorship statement}

Author contributions: Concept - B.K.; Design - B.K.; Supervision - B.K.; Resource - 3rd District Izmir Chamber of Pharmacist.; Materials - ; Data Collection and/or Processing - B.K., E.G.K.; Analysis and/or Interpretation - B.K., E.G.K.; Literature Search - B.K., E.G.K.; Writing - B.K., E.G.K.; Critical Reviews - B.K.

\section{Conflict of interest statement}

The authors declared no conflict of interest.

\section{REFERENCES}

[1] Ölçer F. İşletmelerde Kariyer Yönetimi. Amme İdaresi Derg 1997;30(4):87-103.
[2] Taşliyan M, Arı NÜ, Duzman B. İnsan Kaynakları Yönetiminde Kariyer Planlama Ve Kariyer Yönetimi: İİF Öğrencileri Üzerinde Bir Alan Araştırması, Organizasyon Ve Yönetim Bilimleri Derg 2011; 3(2):231-241.

[3] Türk Dil Kurumu, Büyük Türkçe Sözlük http://www.tdk.gov. tr/index.php?option=com_bts\&arama=kelime\&guid=TDK. GTS.59195d79aaad1.70094250 (accessed: April 02, 2017).

[4] Balta Aydın E. Yüksek Lisans Tezi, Örgütlerde Kariyer Yönetimi, Kariyer Planlaması, Kariyer Geliştirmesi Ve Bir Kariyer Geliştirme Programı Olarak Koçluk Uygulamaları, Pamukkale Üniversitesi Sosyal Bilimler Enstitüsü İşletme Anabilim Dalı Yönetim Ve Organizasyon Bilim Dalı Denizli, Türkiye, 2007.

[5] Koca Aİ. Kariyer Seçiminde Kariyer Değerleri İle Demografik Faktör İlişkisi: Çukurova Üniversitesi’nde Bir Araştırma, Çukurova Üniversitesi İİBF Derg 2010;14(1):56-70.

[6] Çarıkçı İH, Erdoğan Morçin S. Önlisans Turizm Öğrencilerinin Kariyer Değerleri: Sarıkamış Örneği. EJOIR 2014;2 (Özel Say1): 67-81.

[7] Topkaya Ö. Dünyada Endüstriyel Robot Sektörü Ve Çalışma Hayatına Etkileri. Atatürk Üniversitesi İİBF Derg 2016;30(5):1129-1143.

[8] Akoğlan Kozak M, Dalkıranoğlu T. Mezun Öğrencilerin Kariyer Algılamaları: Anadolu Üniversitesi Örneği. AÜSBD 2013;13(1):41-52.

[9] Özden MC. Üniversite Yönetmelikleri Çerçevesinde Kariyer Merkezlerinin Amaç ve Faaliyetleri. KSBD 2015;7(12):145-169.

[10] Şahin İ, Zoraloğlu RY, Firat NŞ. Üniversite Öğrencilerinin Yaşam Amaçları, Eğitsel Hedefleri, Üniversite Öğreniminden Beklentileri ve Memnuniyet Durumları. Kuram ve Uygulamada Eğitim Yönetimi Derg 2011;17(3):429-452.

[11] Çalışma Genel Müdürlüğü/Sendika Üyeliği ve İstatistik Daire Başkanlığı, Asgari Ücretin Net Hesabı ve İşverene Maliyeti https://www.csgb.gov.tr/media/1692/2016_onikiay.pdf (accessed: June 12, 2017).

[12] Pehlivan R. Yüksek Lisans Tezi, Lisans Düzeyinde Turizm Eğitimi Almakta Olan Öğrencilerin Sektör İle İlgili Tutumlarının Mezuniyet Sonrası Kariyer Seçimine Etkisi, Adnan Menderes Üniversitesi, Sosyal Bilimler Enstitüsü Turizm İşletmeciliği Anabilim Dalı Aydın Türkiye, 2008.

[13] Viola KV, Bucholz E, Yeo H, Piper CL, Bell RH, Ann Sosa J. Impact of family and gender on career goals: Results of a national survey of 4586 surgery residents. Arch Surg. 2010;145(5):418-424.

[14] Çiftçi C, Çağlar A. Ailelerin sosyo-ekonomik özelliklerinin öğrenci başarısı üzerindeki etkisi: Fakirlik kader midir? JHS 2014;11(2):155-175.

[15] Türkiye İstatistik Kurumu, Kazanç Yapısı Araştırması, 2014. http://www.tuik.gov.tr/PreHaberBultenleri.do?id=18861 (accessed: June 12, 2017).

[16] Wilson K, Jesson J, Langley C, Hatfield K, Clarke L. Pharmacy Undergraduate Students: Career Choices \& Expectations Across A Four-Year Degree Programme, Aston University, 2006.

[17] Çiftçi GE, Bülbül SF, Bayar Muluk N, Çamur Duyan G, Yılmaz A. Sağlık Bilimleri Fakültesini Tercih Eden Öğrencilerin, 
Üniversite ve Meslek Tercihlerinde Etkili Olan Faktörler (Kırıkkale Üniversitesi Örneği). J Kartal TR 2011;22(3):151160.

[18] Soerlie V, Talseth AG, Norberg A. Male nurses reasons for entering and experiences of being in the profession. Scand J Caring Sci 1997;11:113-118.

[19] Kıran B. Taşkıran EG. Ege Üniversitesi Eczacıllk Fakültesi 1.sınıf öğrencilerinin meslek tercihine etki eden faktörler. Marmara Pharm J 2015;19:159-167.

[20] Aydın O, Çiftel N. Ortaöğretim Kurumlarına Devam Eden Öğrencilerin Akademik Ve Mesleki Gelecek Kaygılarının İncelenmesi. İZÜ Sosyal Bilimler Derg. 2013 Güz Dönemi 3, 129-166

[21] Ayyıldız Y. Meslek Lisesi son sınıf öğrencilerinin sosyodemografik özelliklerine göre işsizlik kaygılarının incelenmesi. ASOS Journal 2015;3(20):175-187

[22] Super DE. A life-span life-space approach to career development. JVB 1980;16(3):282-298.
[23] Özdemir Yaylacı G. İlköğretim düzeyinde kariyer eğitimi ve danışmanlığı. Bilig 2007;40:119-140.

[24] Polat FB, Ardıç K, Özdemir Y. Bireysel kariyer planlamada etkili olan faktörlerin belirlenmesine yönelik bir araştırma: Sakarya Devlet Okulları Örneği. JOBS 2016;4(1):29-65.

[25] Akıntuğ Y, Birol C. Lise öğrencilerinin mesleki olgunluk ve karar verme stratejilerine yönelik karşılaştırmalı analiz. HUJE 2011;41:1-12.

[26] Sav D. Yüksek Lisans Tezi, Bireysel Kariyer Planlamada Etkili Olan Faktörler Ve Üniversitelerin Etkisi Üzerine Bir Araştırma, Süleyman Demirel Üniversitesi Sosyal Bilimler Enstitüsü İşletme Anabilim Dalı, Isparta, Türkiye, 2008.

[27] Cevher E. Üniversitelerde kariyer planlama faaliyetleri ekseninde kariyer merkezlerine yönelik bir araştırma. Karabük Üniversitesi Sosyal Bilimler Enstitüsü Derg 2015;5 (2):164-177.

[28] Yüksek Öğretim Kurulu, Kariyer Merkezleri Toplantısı 13 Haziran 2013 http://www.yok.gov.tr (accessed: April 11, 2017). 